doi: 10.18575/msrs.sm.e.18.03 UDC: 615.265 .2

COBISS.RS-ID: 7316760

\title{
Physicochemical Equivalence Studies of Two Amlodipine Tablet Formulations
}

\begin{abstract}
Introduction: Based on the international drug regulatory requirements, all generic pharmaceutical manufacturers are obliged to ensure that their generic products are similar or equivalent to the innovative brand. The quality of generic medicines should be comparable with the innovator brand and therefore interchangeable with the innovator. Based on the Biopharmaceutical Classification System (BCS), dissolution tests can be used as a replacement for in vivo studies for drugs that belong to the BCS class I. Dissolution tests are considered the most sensitive in vitro parameters that can be with the highest probability of correlation with in vivo bioavailability. The comparison of in vitro dissolution tests using similarity factor (f2) is very often used as the most important parameter that can reflect the existence of bioavailability.
\end{abstract}

Aim of the Study: The aim of this study was to compare the physico-chemical characteristics of two amlodipine formulations made by the same manufacturer using the dissolution test and similarity factors to ascertain their in vitro similarity.

Material and methods: Two different generic copies of amlodipine $5 \mathrm{mg}$ tablets produced by the same pharmaceutical manufacturer were evaluated using pharmaceutical parameters such as: uniformity of active ingredient test, weight uniformity text, disintegration test, hardness test, tablet friability test, and in vitro dissolution test.

Results: The results have shown that different salts and different manufacturing procedures do not have effect on in vitro equivalence of amlodipine tablets. The similarity factor (f2) at $\mathrm{pH} 4.5,1.2$ and 6.8 was 63.90, 53.87 and 57.57, respectively. Although these values demonstrated equivalence, statistically significant differences were found in the degree of dissolution rates of tablets formulation depending on time and $\mathrm{pH}$ values. The results of our study showed equivalence of dissolution profiles of different amlodipine formulations.

Conclusion: The results of our study have shown that the equivalence of dissolution profiles exists, although there were statistical differences in some pharmaceutical parameters.

Key words: amlodipine besylate, amlodipine mesylate, pharmaceutical formulation, dissolution

(Scr Med 2018:49:18-24)

\section{Sanja Kecman ${ }^{1,2}$ Svetlana \\ Goločorbin-Kon ${ }^{2,3}$, Momir Mikov ${ }^{2,4}$}

${ }^{1}$ Hemofarm d.o.o, a Member of Stada Group,. Banja Luka, The Republic of Srpska, Bosnia and Herzegovina

${ }^{2}$ Department of Pharmacy, Faculty of Medicine, University of Banja Luka, Banja Luka, Republic of Srpska, Bosnia and Herzegovina ${ }^{3}$ Department of Pharmacy, Faculty of Medicine, University of Novi Sad, Novi Sad, Serbia

${ }^{4}$ Department of Pharmacology, Toxicology and Clinical Pharmacology, Faculty of Medicine, University of Novi Sad, Novi Sad, Serbia

Contact address:

Sanja Kecman,

Hemofarm doo,

Street address: Novakovići bb

78 ooo Banja Luka,

Republic of Srpska,

Bosnia i Herzegovina e-mail:

sanja.kecman@hemofarm.com phone number: +387-65-519-58o

Submitted: March $6^{\text {th }}, 2018$ Accepted: March 18 ${ }^{\text {th }}, 2018$ 


\section{Introduction}

Amlodipine is a dihydropyridine calcium channel antagonists that inhibits the influx of extracellular calcium into vascular and cardiac cells via blockade of voltage-dependent L-type calcium channels. ${ }^{1,2}$ This class of cardiovascular drugs lowers blood pressure through relaxation of vascular smooth muscles and vascular dilatation. It is the most frequently used calcium channel antagonist worldwide, indicated for the treatment of hypertension and coronary artery disease, well tolerated by the majority of patients with very moderate to mild side effects. ${ }^{3}$ Amlodipine has slow elimination rate with prolonged half-life ( $\mathrm{t} 1 / 2>35$ hours) resulting in long duration of action. ${ }^{4}$

Amlodipine was patented by Pfizer under the brand name Norvasc. After the patent right expired in late 2007, a number of generic versions of amlodipine became available. ${ }^{5}$ Tablets of amlodipine from different or same producers may contain different salts. Based on internationally drug regulatory requirements, all generic pharmaceutical manufacturers are obliged to ensure that their generic products are similar or equivalent to the innovative brand. A generic medicine is defined as a faithful imitation of an original drug, which is not protected by a patent, and marketed with the chemical name of the active ingredient. ${ }^{6}$ Quality of generic medicines should be comparable with the innovator brand and therefore interchangeable with the innovator.

Two different generic copies of amlodipine $5 \mathrm{mg}$ tablets, produced by the same pharmaceutical manufacturer, were evaluated using pharmaceutical parameters such as: uniformity of active ingredient test, weight uniformity text, disintegration test, hardness test, tablet friability test, and in vitro dissolution test. These tests are required by most drug regulatory authorities to ascertain the claim of pharmaceutical equivalency. Based on the Biopharmaceutical Classification System (BCS), dissolution tests can be used as a replacement for in vivo studies for drugs that belong to the BCS class I. ${ }^{7}$ Dissolution tests are considered the most sensitive in vitro parameters that can be with the highest probability of correlation with the in vivo bioavailability. Very often, comparison of dissolution tests in vitro, using similarity factor (f2) is used as the most important parameter that can reflect the existence of bioavailability. ${ }^{8}$

\section{Aim of the Study}

The aim of this study was to compare the physicochemical characteristics of two amlodipine formulations made by the same manufacturer using the dissolution test and similarity factors to ascertain their in vitro similarity.

\section{Material and methods}

Materials

In order to assess physico-chemical equivalence, two generic brands of amlodipine from the EU market were used.

Two different formulations of amlodipine, with different salts of amlodipine $5 \mathrm{mg}$, amlodipine besylate (formulation 1), and amlodipine mesylate (formulation 2) were used.

\section{Tablet formulation 1}

The method used in preparation of formulation 1 was wet granulation. After mixing amlodipine besylate and starch, microcrystalline celullose and magnesium stearate were added in preparation for the tableting.

\section{Tablet formulation 2}

The method used in preparation of formulation 2 was dry mixing. After mixing amlodipine mesylate with calcium hydrogen phosphate, sodium starch glycolate microcrystalline celullose and magnesium stearate were added. The next step was tableting.

\section{Chemicals}

Chemicals used for these analyses were: potassium dihydrogen phosphate ( $\mathrm{KH}_{2} \mathrm{PO}_{4}$ ) p.a, $1 \mathrm{M}$ solution of sodium hydroxide p.a, concetrated hydrochloric acid $(37 \% \mathrm{HCl})$ p.a, sodium acetate $\mathrm{x} 3 \mathrm{H} 2 \mathrm{O}$ p.a, $2 \mathrm{~N}$ acetic acid p.a, purified water (HPLC grade), triethylamin p.a, phosphoric acid conc.p.a, methanol (HPLC grade), acetonitrile (HPLC grade), triethylamin buffer: disolve $7.0 \mathrm{ml}$ triethylamine in $1000 \mathrm{ml}$ water and adjusted $\mathrm{pH}$ on $3.0 \pm 0.1$ by phosphoric acid, ammonium acetate (HPLC grade) were used.

\section{Apparatus}

Apparatus used for analyses were: Friabilator, Erweka TAR 100; Erweka hardness tester, Erweka TBH 425; Apparatus II (USP paddle apparatus) Erweka DT 800; Scale, Sartorius Practum 213-1S; HPLC, Agilent 1100 Series.

\section{In-process parameters}

In-process parameters included measurement of tablets core weight $(\mathrm{mg}$ ) and uniformity of mass using the method described in Ph. Eur. 2.9.5 and hardness (Ph. Eur.2.9.8), friability (Ph. Eur.2.9.7), disintegration time (Ph. Eur.2.9.1.). Analysis of final product is related to the following parameters: the content of amlodipine in tested formulations was determined by using the method of high pressure liquid chromatography (HPLC), and 
dissolution profile were handled by using the paddle method (Method II, Paddle, Ph. Eur.). ${ }^{9}$

The content of amlodipine tablets

The content of amlodipine besylate in the tested formulation was determined by HPLC on column Zorbax

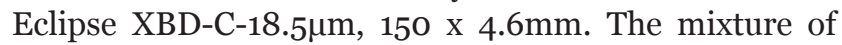
solution triethylene buffer $\mathrm{pH}$ 3.0: acetonitrile: methanol (500:150:350) was used as a mobile phase; flow rate 1.0 $\mathrm{ml} /$ min, temperature: $25^{\circ} \mathrm{C}$, detection: UV/VIS $237 \mathrm{~nm}$; injection volume $10 \mu$ l. Referent solution was prepared by measurement of $35 \mathrm{mg}$ amlodipine besylate as a reference substance and its disintegration in the mobile phase up to $50 \mathrm{ml}$. A sample of $5 \mathrm{ml}$ of obtained solution was completed with a mobile phase up to $50 \mathrm{ml}$. The tested solution was prepared by measuring amlodipine tablets up to $5 \mathrm{mg}$, dissolved with $25 \mathrm{ml}$ mobile phase. After 30 minutes of mixing in ultrasonic baths, solution was cooled up to $25^{\circ} \mathrm{C}$ and combined with a mobile phase up to 500 $\mathrm{ml}$, and after centrifuge the supernatant was filtrated through a membrane filter $45 \mu \mathrm{m}$. A sample of $5 \mathrm{ml}$ was diluted with a mobile phase up to $100 \mathrm{ml}$. Evaluation and calculation of amlodipine besylate content in the tested formulations were performed according to the external standard with the use of peak heights / areas.

The content of amlodipine mesylate in the tested formulation was determined by HPLC on column

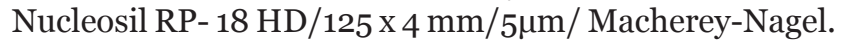
The mixture of ammonium acetate: water: acetonitrile (3.75:750:250) was used as a mobile phase A, titrated to $\mathrm{pH}$ 6.0 used with acetic acid, and acetonitrile (HPLC purity) was used as a mobile phase $\mathrm{B}$; with flow rate of $1.0 \mathrm{ml} / \mathrm{min}$, temperature: $40{ }^{\circ} \mathrm{C}$, detection: $\mathrm{U} 240 \mathrm{~nm}$, injection volume: $10 \mu \mathrm{l}$. Referent solution was prepared by measuring $24-26 \mathrm{ml}$ amlodipine mesylate as a referent standard and mixing 15 min with $5 \mathrm{ml} \%$ acetic acid. The obtained solution was completed with a mobile phase A up to $50 \mathrm{ml}$. The solution was mixed for 2 minutes in ultrasonic baths. The tested solution was prepared by measurement of 10 tablets dissolved with $10 \mathrm{ml} 1 \%$ acetic acid. After mixing for $15 \mathrm{~min}$, the obtained solution was dissolved in the mobile phase B up to $50 \mathrm{ml}$ and mixed in the ultrasonic baths for 5 minutes. After a centrifuge on $4000 \mathrm{rpm}$ for 5 minutes, supernatant was used for injection.

Estimation/Evaluation and calculation of the amlodipine besylate and amlodipine mesylate content in the tested formulations were based on the external standards with the use of peak area. The value of the content of amlodipine in the tested tablets was calculated by using a software. Validation characteristics: specificity, accuracy, precision, linearity, range and reproducibility were tested..$^{10,11}$

\section{Dissolution profiles}

Defining dissolution profile of both tested formulations was performed with 12 tablets each. Tests were handled by using the paddle method (Method II, Paddle, Ph.Eur.) 9 on spectrophotometer Agilent 8453 in three different media. Medium 1: phosphate buffer Ph 6.8 (Ph.Eur): $0.68 \%$ sodium hydrogen phosphate $\mathrm{pH} 6.8$ with $1 \mathrm{M}$ sodium hydroxide. Medium 2: acetate buffer $\mathrm{pH} 4.5$ (USP): $14 \mathrm{ml} 2 \mathrm{~N}$ of acetic acid was added in $2.99 \mathrm{~g}$ of sodium acetate trihydrate and dissolved with water up to 1000.0 ml. Medium 3 : hydrochloric acid $0.1 \mathrm{M}: 8.5 \mathrm{ml}$ concentrated hydrochloric acid (HCL 37\%) completed in $1000.0 \mathrm{ml}$ of water (pH 1.2). Media volume of $900 \mathrm{ml}$, at the rotation speed of $100 \mathrm{rpm}$ and the temperature of $37^{\circ} \mathrm{C} \pm 0.5$ was used. Amlodipine besylate and amlodipine mesylate were used as the reference standard. The reference solution was prepared by dissolving $38 \mathrm{mg}$ of referent substance in $500 \mathrm{ml}$ of diluent, after that $5 \mathrm{ml}$ of the obtained solution was combined with the $50 \mathrm{ml}$ of diluent. The tested solutions, prepared in the same way, were filtrated through the membrane filter of $0.45 \mu \mathrm{m}$. Measurements were done by the spectrophotometric method at $239 \mathrm{~nm}$. The average values of dissolution in all samples were obtained according to the calculation and expressed as a percentage of released active substance in defined time intervals. Obtained values were used for calculating similarity factors by formula: ${ }^{8}$

$$
\mathrm{f}_{2}=50 \times \log \left[\left[1+(1 / \mathrm{n}) \Sigma \mathrm{t}=1 \mathrm{n}(\mathrm{Rt}-\mathrm{Tt})^{2}\right]^{-0,5} \times 100\right]
$$

Similarity factor is a logarithmic reciprocal square root transformation of a sum of squared error and is a measurement of the similarity between the two curves, expressed in percentages ( $\mathrm{n}$ - number of samples, $\mathrm{Rt}$ - dissolution value of formulation 1 at time $\mathrm{t}, \mathrm{Tt}$ dissolution value formulation 2 at time $\mathrm{t}$ ).

\section{Statistical analysis}

Statistical analysis of the in-process communication parameters (IPC) as well as the content of amlodipine besylate were expressed using average values and standard deviations. The results were processed by t-test for IPC parameters and analysis of variance (ANOVA). 


\section{Results}

In-process parameters

Analysis of IPC parameters showed a significant difference in average weight of tablet cores and disintegration time, but not in their hardness, friability and mass uniformity. The content of active substance was within the specification range in both formulations (table 1).

Table 1. Comparative data of pharmaceutical parameters for two amlodipine formulations

\begin{tabular}{|c|c|c|c|c|c|c|}
\hline Tablets & $\begin{array}{l}\text { Average weight } \\
\text { (g) }\end{array}$ & Hardness & $\begin{array}{l}\text { Friability } \\
(\%)\end{array}$ & $\begin{array}{l}\text { Disintegration } \\
\text { time (min.) }\end{array}$ & $\begin{array}{l}\text { Uniformity of } \\
\text { mass }\end{array}$ & $\begin{array}{c}\text { Content } \\
\text { tbl): }\end{array}$ \\
\hline Formulation 1 & $\begin{array}{c}0.149 \\
(0.148-0.153)\end{array}$ & $\begin{array}{c}98.20 \\
(93-104)\end{array}$ & $\begin{array}{c}0.00 \\
(\max 0.1 \%)\end{array}$ & 0.53 & $-1.3 \% /+2 \%$ & $\begin{array}{c}4.87 \\
(4.85-5.15)\end{array}$ \\
\hline Formulation 2 & $\begin{array}{c}0.201 \\
(0.198-0.204)^{\star}\end{array}$ & $\begin{array}{c}103.5 \\
(95-117)\end{array}$ & $\begin{array}{c}0.02 \\
(\max 0.1 \%)\end{array}$ & $0.33^{*}$ & $-2 \% /+1 \%$ & $\begin{array}{c}5.02 \\
(4.75-5.25)\end{array}$ \\
\hline
\end{tabular}

$*=P<0.001$

Dissolution profiles of tested formulations and similarity factors

According to the World Health Organisation (WHO), quick release criteria will be satisfied if release of active substance is more than $85 \%$ in water media within 30 minutes, $\mathrm{pH}$ range 1.0 - 6.8. Release studies were conducted at $\mathrm{pH}$ 1.2, $\mathrm{pH} 4.5$ and $\mathrm{pH} 6.8$ buffer media . The dissolution rate of the formulation 2 was lower in all tested media during the first 30 minutes, but it increased in the following period and become higher than in the formulation 1. The more detailed data of dissolution values of tested formulations in different $\mathrm{pH}$ media are shown in figures 1-3.

Figure 1. Average dissolution values of tested samples $(n=12)$ at defined time intervals at $\mathrm{pH} 6.8$

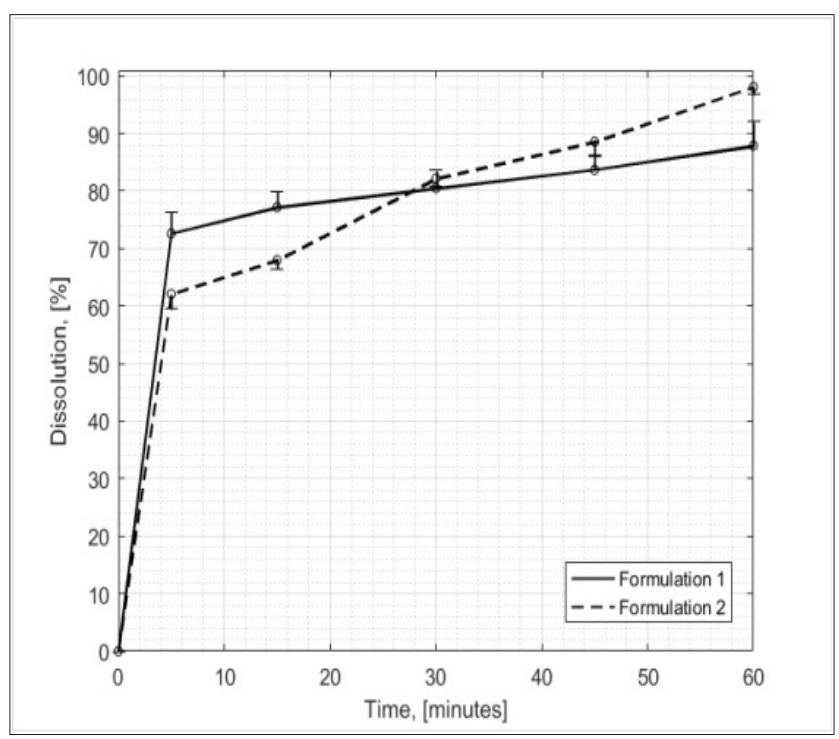

Figure 2. Average dissolution values of tested samples ( $\mathrm{n}=12$ ) at defined time intervals at $\mathrm{pH} 4.5$

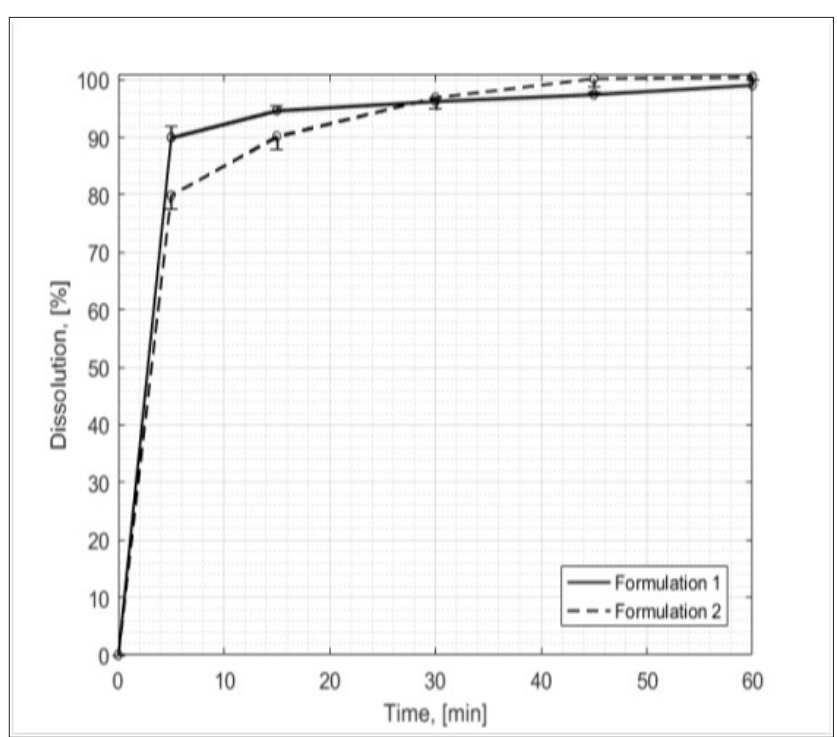

The value of the calculated similarity factor in in vitro conditions showed that the dissolution profiles of the tested formulations were equivalent at all tested conditions. Dissolution rate in lower $\mathrm{pH}$ values, in both formulations, was extremely fast, and after 5 minutes between $80 \%$ and $90 \%$ of the active substances were released. The value of the obtained similarity factor (f2) at $\mathrm{pH} 4.5$ was 63.90 , while at $\mathrm{pH} 1.2$ it was 53.87 (figures 2 and 3 ).

The dissolution rate at higher $\mathrm{pH}$ value (6.8) was lower in both formulation, so the dissolution profiles of tested formulation were similar (f2 $=57.57$ ). Although the in vitro equivalence was confirmed at the tested $\mathrm{pH}$, there 
was a statistically significant difference in the values of the dissolutions for both formulations at all time intervals, except for the time of 30 minutes, which was confirmed by the analysis of variance (figures 1-3).

Further analysis showed statistically significant differences in dissolution rates of both formulations at pH 6.8 compared to $\mathrm{pH} 4.5$ and $\mathrm{pH} 1.2$, respectively, while these differences were not significant at $\mathrm{pH}$ values of 4.5 and 1.2 .

Figure 3. Average dissolution values of tested samples ( $\mathrm{n}=12$ ) at defined time intervals at $\mathrm{pH} \mathbf{1 . 2}$

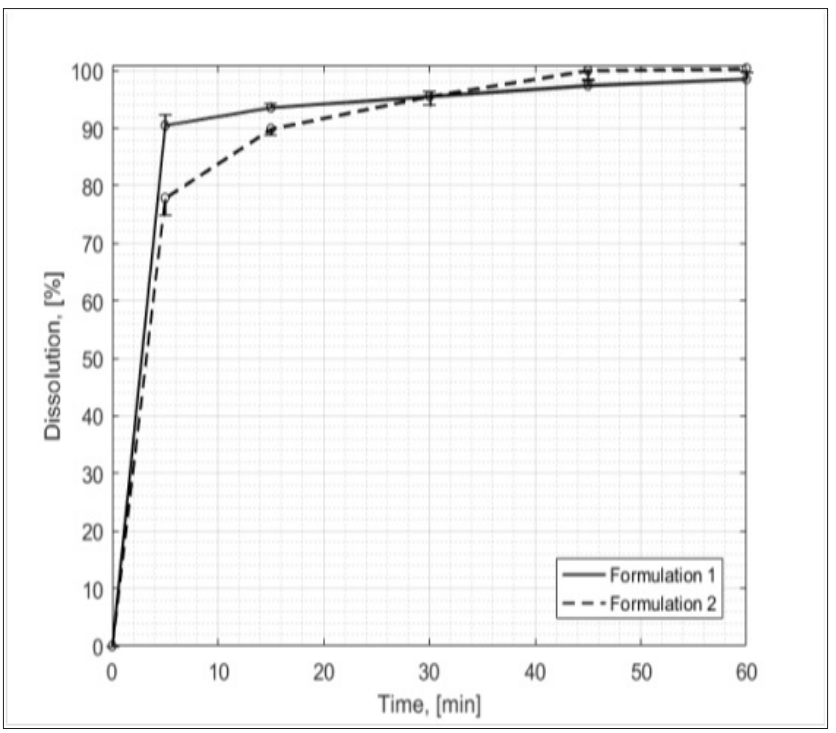

\section{Discussion}

The comparison of two amlodipine formulations prepared by different manufacturing procedures showed that they were different in average weight and time of disintegration, but similar in dissolution profiles. In some studies that evaluated different brands of amlodipine tablets, the different disintegration time of tested tablets were observed, without having an impact on dissolution rate. ${ }^{12,13}$

In this study, the tablet formulation of amlodipine besylate showed slower dissolution rate (88 - 98\%) in comparison with amlodipine mesilate (about $98-100$ \%) after 60 minutes, due to the different manufacturing procedures; wet granulation vs. dry mixing, respectively. Amlodipine mesylate prepared by dry mixing had higher proportion of small particles than amlodipine besylate prepared by wet granulation. For both amlodipine formulations dissolution rates were higher and faster in media with lower acidity ( $\mathrm{pH} 1.2$ and 4.5), but the dissolution rate was lower in less acide media $(\mathrm{pH}$ 6.8). All the above mentioned corresponds to the study performed by Akinleye et al. 12 and Shohin et al. ${ }^{14}$

The obtained results of the study, which confirm the equivalence of the tested formulations, are in accordance with studies of Shohin et al. ${ }^{14}$ and Oyeniyi et al. ${ }^{15}$ but in contrast with a similar study of Olusola et al.7, where equivalence at $\mathrm{pH} 4.5$ was not established in one of the tested formulations, even though it was equivalent at $\mathrm{pH}$ 1.2 and 6.8. In another study of Pant et al.. ${ }^{16}$ there where equivalence of tested formulations only at $\mathrm{pH} 1.2$.

Problems related to the pharmaceutical equivalence are presented by a few authors, who dealt with different active substances such as tetracycline capsules, ${ }^{17}$ nifedipine retard tablets $^{18}$ and metronidazole tablets. ${ }^{19}$ The possible reasons for non-equivalence of pharmaceutical preparations in these studies could be attributed to variations of pharmaceutical parameters of the tested formulations. Therefore, the high dissolution rates of tested tablets do not automatically guarantee their in vitro equivalence.

\section{Conclusion}

In spite of the evident differences in disintegration times and dissolution rates of the formulations and media used, it can be considered that equivalence of both amlodipine formulations exists in in vitro conditions in all three media tested. Theoretically, there is a possibility that amlodipine besylate and amlodipine mesylate could be considered as bioequivalent, without performing classical bioequivalence studies.

\section{References}

1. Murdoch D, Heel RC. Amlodipine. Drugs 1991;41(3):478505 .

https://doi.org/10.2165/00003495-199141030-00009 PMid:1711448

2. Kass RS, Arena JP, DiManno D. Block of heart calcium channels by amlodipine: influence of drug charge on blocking activity. J Cardiovasc Pharmacol 1988;12(Suppl 7):S45-S49.

https://doi.org/10.1097/00005344-198812007-00010 PMid:2467128

3. British National Formulary 74, BMJ Group and the Royal Pharmaceutical Society of Great Britain Publishing, London, UK, 2017.

4. van Zwieten PA. Amlodipine: an overview of its pharmacodynamic and pharmacokinetic properties. Clin Cardiol 1994;17(9 Suppl 3):III3-III6.

PMid:9156957

5. Franck RG. The Ongoing Regulation of Generic Drugs. N 
Engl J Med 2007;367(20):1993-6. https://doi.org/10.1056/NEJMpo78193 PMid:18003956

6. Garattini L, Tediosi F. A comparative analysis of generics markets in five European countries. Health Policy 2000; 51:149-62. https://doi.org/10.1016/So168-8510(oo)ooo61-o

7. Olusola AM, Olubukola OO, Emeka OH, Lilian AE. Equivalence of two generic brands of amlodipine besylate under biowaiver conditions. Int $\mathrm{J}$ Pharm Pharm Sci 2012;4(2):265-8.

8. Welling PG. Pharmacokinetics, Processes and Mathematics. Washington, DC: American Chemical Society, 1986. p 35-76. PMid:3818845

9. European Pharmacopeia. 9th Edition, 2017. Available at https://www.edqm.eu/en/european-pharmacopoeia-9thedition

10. Guidance for Industry Q2(R1). Validation of Analitical Procedures. Available at https://www.ich.org/fileadmin/ Public_Web_Site/ICH_Products/Guidelines/Quality/ Q2_R1/Step4/Q2_R1_Guideline.pdf （ accessed November 2005 ICH.)

11. Guidance for Industry. Analitical procedures and Methods Validation FDA -CDER-CBER. Available at https:// www.fda.gov/downloads/drugs/guidances/ucm 386366 . pdf (accessed July 2015.)

12. Akinleye MO, Awodele EO, Idris O, Oladimeji- Salami J. The physicochemical equivalence of eight brands of amlodipine tablets in lagos Nigeria. West Afr J Med 2012;
31 (3): 154-159.

PMid:23310934

13. Eraga SO, Uzochkwu OC, Iwuagwu MA. Pharmaceutical Equivalence of some brands of $5 \mathrm{mg}$ amlodipine besylate tablets available in Southern Nigeria. West Afr J Pharm 2014; 25(1): 38-45

14. Shohin IE, Ramenskaya GV, Vasilenko GF, Malashenko EA. In vitro Dissolution Kinetics of Amlodipine Tablets Marketed in Russia Under Biowaiver Conditions. https://doi.org/10.14227/DT170310P2O

15. Oyeniyi YJ, Acho MA. Comparative pharmaceutical evaluation of amlodipin (5mg) tablets registered in Nigeria by NAFDAC, and marketed by various pharmaceutical companies nationwide. Int J Pharm Pharm Sci 2011;3 Suppl 5:446-8.

16. Pant T, Mishra K, Subedi RK. In vitro studies od amlodipine besylate tablet and comparson with foreign brand leader in Nepal. Int J Pharm Sci Res 2013; 4(10):3958-3964.

17. Okeke I, Lamikanra A. Quality and bioavailability of tetracycline capsule in Nigera semi-urban community. Int J Antimicrob Agents 1995; (5): 245-250. https://doi.org/10.1016/0924-8579(94)0oo64-2

18. Okoye EI, Iwuagwu MA. Physichochemical equivalence of some brands of Nifedipine retard tablets available in Nigeria. Afr J Biotechnol 2010; 9(8) :1274-1279. https://doi.org/10.5897/AJB09.1466

19. Usman MA, Eniolorunda RO, Sule MI, Hassan HS, Salisu IM, Sallah A, Bashir DB. Chemical equivalence studies od four brands of Metronidazole tablets. Niger J Pharm Sci 2010; 9(1): 90-95. 


\section{Ispitivanje fizičko-hemijske ekvivalencije dvije tabletne formulacije amlodipina}

\section{SAŽETAK}

Uvod: Na osnovu međunarodnih regulatornih zahtjeva za lijekove, svi proizvođači generičkih lijekova su obavezni da obezbijede da njihovi generički proizvodi budu slični ili ekvivalentni ovom inovativnom brendu. Kvalitet generičkih lijekova bi trebalo da bude uporediv sa originalnim lijekom i stoga i zamjenjiv sa istim. Na osnovu Biofarmaceutskog sistema klasifikacije (BSC), ispitivanje brzine rastvaranja se može koristiti umjesto in vivo studija za lijekove koji pripadaju BSC klasi I. Testovi rastvaranja se smatraju najosjetljivijim in vitro parametrima koji mogu imati najviši nivo korelacije sa in vivo biološkom raspoloživošću. Veoma često se poređenje in vitro testova rastvaranja, uz određivanje faktora sličnosti (f2), koristi kao najvažniji parametar koji može da odražava postojanje biološke raspoloživosti.

Cilj rada: Cilj ove studije je bio da se uporede fizičko-hemijske karakteristike dvije formulacije amlodipina istog proizvođača i određivanjem faktora sličnosti utvrdi njihova farmaceutska ekvivalentnost.

Materijal i metode: Tokom studije izvršena je evaluacija dvije različite formulacije tableta amlodipina 5 mg proizvedene od strane istog proizvođača. Evaluacija je izvršena korištenjem farmaceutskih parametara poput: uniformnost sadržaja, uniformnosti mase, test raspadljivosti, test tvrdoće, test habanja tablete i test in vitro rastvorljivosti (disolucija).

Rezultati: Rezultati pokazuju da različite soli i različite proizvodne procedure ne utiču na ekvivalentnost tablete amlodipina in vitro. Faktori sličnosti (f2) pri pH 4,5, 1,2 i 6,8 su dobijeni 63,90, 53,87 i 57,57. lako vrijednosti faktora sličnosti ukazuju na farmaceutsku ekvivalentnost, u stepenu rastvaranja utvrđene su statistički u tabletnim u zavisnosti od vremena i pH vrednosti. Rezultati našeg istraživanja pokazali su ekvivalenciju profila rastvaranja različitih formulacija amlodipina.

Zaključak: Rezultati ove studije su pokazali da postoji ekvivalentnost profila rastvaranja tabletnih formulacija amlodipina, iako je utvrđeno postojanje statističkih razlika u nekim farmaceutskim parametrima.

Ključne riječi: amlodipin besilat, amlodipin mesilat, farmaceutska formulacija, disolucija 